\title{
大河川における濁度観測値による 土砂輸送量の計算
}

\author{
CALCULATIONS OF THE SEDIMENT TRANSPORT
} BY TURBIDITY DATA IN A LARGE RIVER CHANNEL

\author{
山口 甲 ${ }^{1}$ 口田村 $一$ 弘 $^{2} \cdot$ 渡 辺 浩 司 $^{3}$ \\ Hajime YAMAGUCHI, Kazuhiro MITAMURA and Kouji WATANABE
${ }^{1}$ 正会員 工博 北海学園大学教授 工学部土木工学科（广064-0926 札幌市中央区南 26 条西 11 丁目 1-1）
${ }^{2}$ 正会員 株式会社 北開水エコンサルタント（テ080-0314＼cjkstart北海道河東郡音更町共栄台西 11 丁目 1） \\ ${ }^{3}$ 正会員 北海道開発局 室蘭開発建設部（T051-8524 室蘭市入江町 1-14）
}

\begin{abstract}
The present study addresses the procedure to predict the time dependent of suspended material loads from discharge hydrographs by using of a newly proposed turbidity function. The turbidity, which is relatively easily measured even during big floods, is a convenient index to understand transport mechanisms of suspended material load. The turbidity has different characteristics in the rising and falling limbs of flood hydrographs. This hysteresis effect in the relationship between turbidity and discharge is modeled by a nonlinear function in the present study. On the basis of simulation results, the turbidity function appears to have effectual methods for predicting suspended material loads.
\end{abstract}

Key Words : suspended material load, bed load, turbidity function

\section{1.まえがき}

積雪寒冷地の大きな流域を持つ河川の土砂流出量は極 めて大きく, その土量はダム貯水池の堆砂, 土砂の氾濫, 河道堆積, 海域拡散等をもたらし, 災害を助長したり, 河川水域の環境変化の原因となっているので，河川流域 を土砂の流砂系として位置づけ，水系全体の土砂動態現 象を究明する必要がある ${ }^{1)}$ 。ところで河道内の流出土砂 量の輸送形態は掃流砂, 浮遊砂, wash load に区分され ているが，形態別の量的実態把握は未だ十分とは言い難 く, また融雪出水と降雨出水, 出水の増水期と減水期等 のS.S の相違等は論じられているものの, 流出土砂量の 算定に反映させるには多くの研究課題が残されている。

本文は, 石狩川流域の流量観測地点において, 土砂輸 送量の観測と 1 時間毎の濁度の連続観測を行い，その資 料を分析して融雪出水・降雨出水の土砂輸送量の相違, 出水の増水期・減水期における土砂輸送量の違いを明ら かにして, 降雨による出水の土砂輸送量を計算する方法 を述べる。

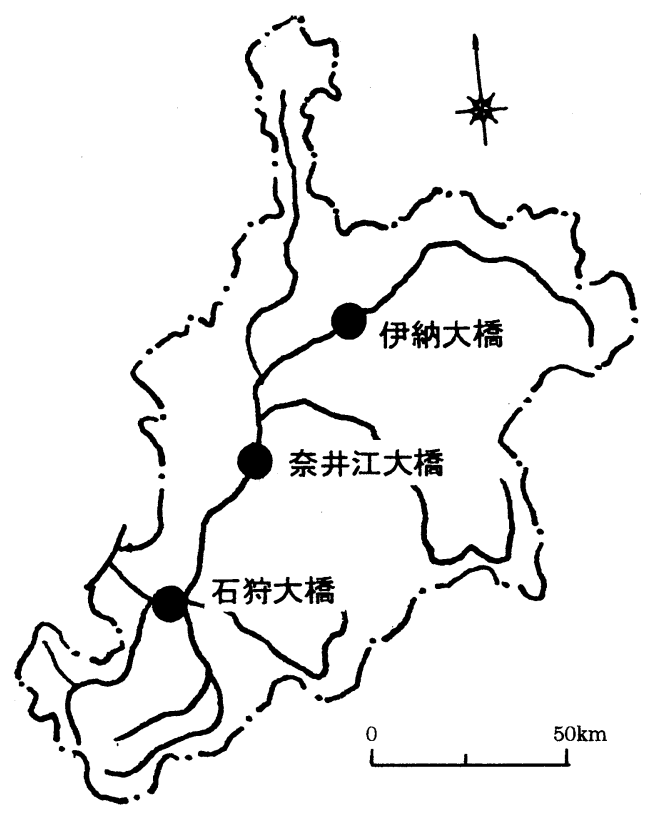

図-1 流送土砂 - 濁度観測位置 
SS

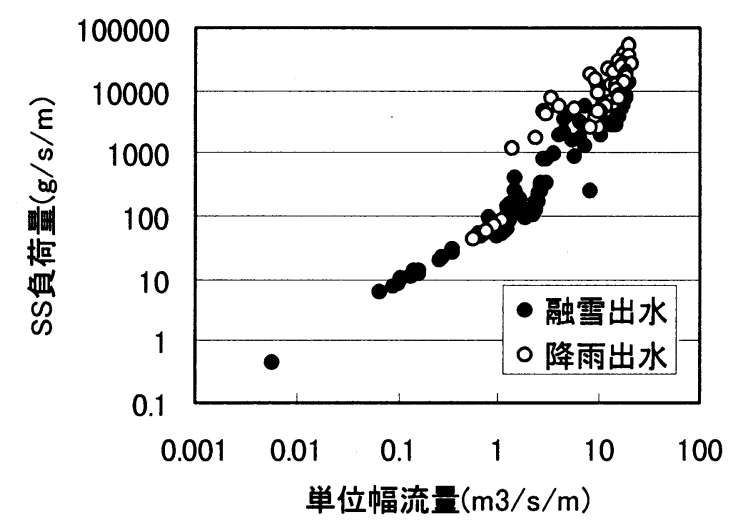

$\mathrm{T}-\mathrm{N}$

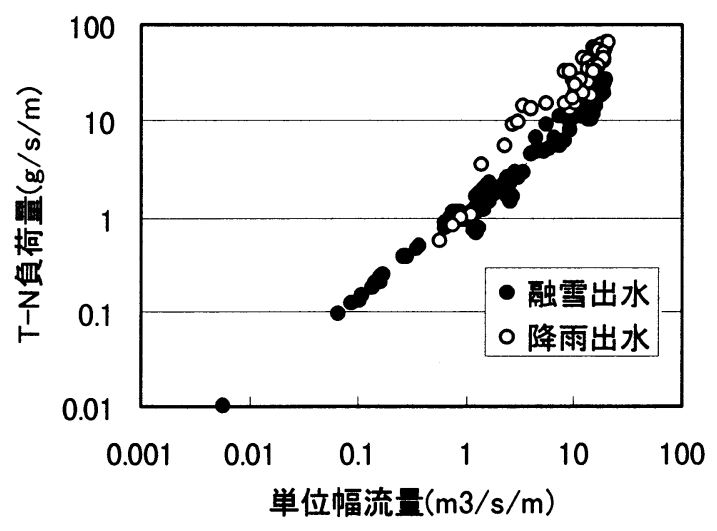

T-P

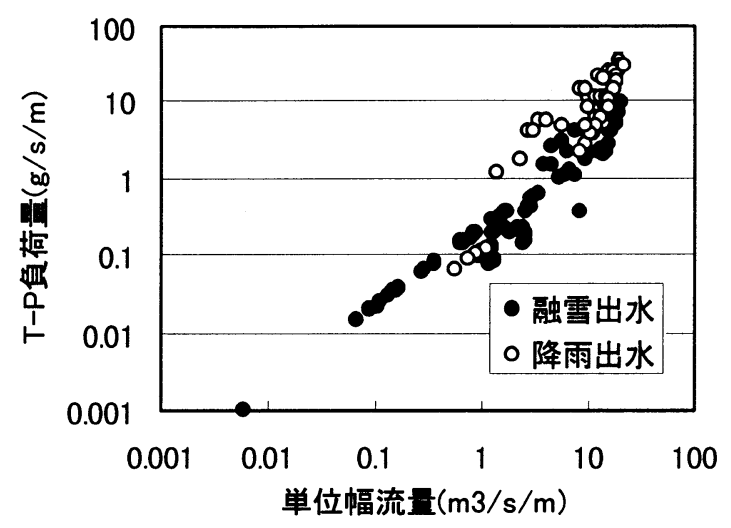

図-2＼cjkstart単位幅当り物質輸送量（奈井江大橋）

\section{2. 土砂輸送量の観測}

\section{（1）土砂輸送量}

観測対象河川である石狩川は総流域面積 $14,330 \mathrm{~km}^{2}$ を 有する大規模河川であり, 流域平均降水量は $1,300 \mathrm{~mm}$ で 年平均 $15 \times 10^{9} \mathrm{~m}^{3}$ の流量によって多量の土砂が運搬され ている。また同一流量での土砂輸送量は降雨出水時に大 きく, 流量の時間変動も大きいが出水期間が短い傾向が

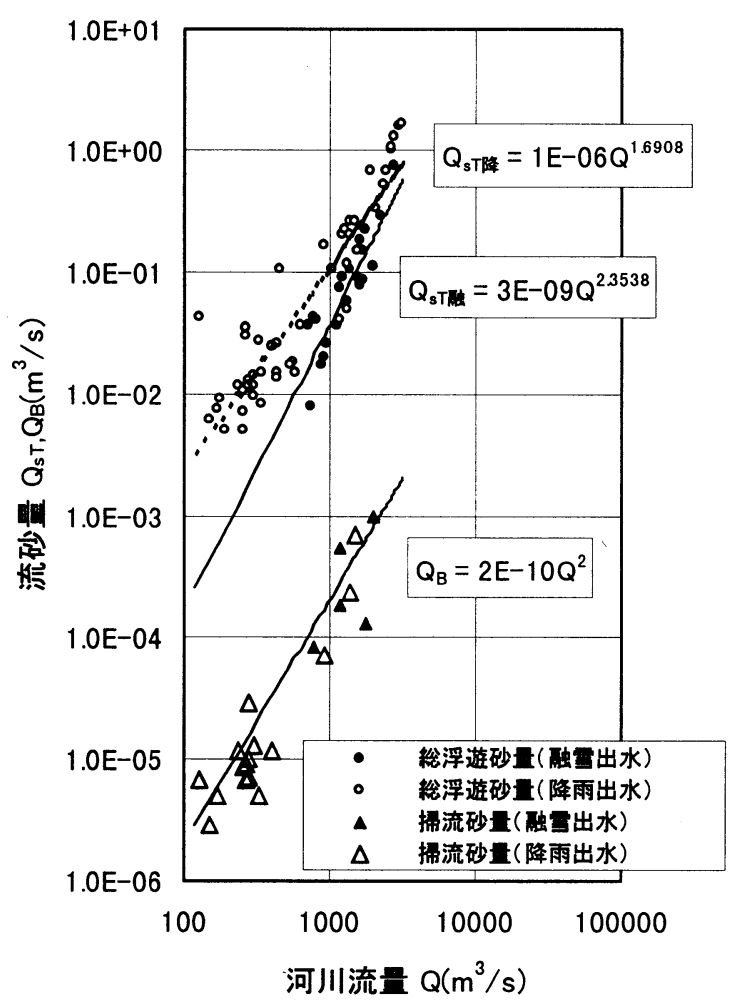

図-3 河川流量と流砂量（石狩大橋）

ある。一方, 融雪出水時の土砂輸送量は小さく，かつ流 量の時間変動が小さいが長時間続くことが多い。

これらの実態を把握するため, 平成 9,10 年に図- 1 に .示す 3 地点で流下物質の観測を行った。観測対象とした 測定項目は，掃流砂，浮遊砂，土砂の粒径，濁度，総窒 素, 総リン及び水深，流速である ${ }^{2)}$ 。掃流砂け士土研式採 砂器を用い, 浮遊砂はバンドーン式採水器で採水して, 粒度分析はコールターカウンター法, S.S は重量法, 濁 度は積分球式光電光度法による。総窒素 $(\mathrm{T}-\mathrm{N})$, 総リン （T-P）は水質分析告示 140 号に基づき計測した。また水 深はロッド，流速はプライス型流速計を用いている。そ れぞれの計測点は, 垂直方向 2 点 (2 割, 8 割), 横断方 向 5 測線である。流速が大きくなり, 計測器具の水中固 定が困難な出水では, 横断方向 4 測線上の水面のみの観 測とした。その一例として河道単位幅当たりの輸送量を 流量との関係で表すと, 図-2 のとおりでいずれの物質と も流量との相関性が見られ，かつ融雪出水と降雨出水で は輸送量に差異が見られることが判明した。また，単位 幅当たりの輸送量は，3 観測所ともおおむね S.S が 100 に対し, 総窒素 1 , 総リン 0.1 の割合で輸送されている が，更にそれぞれの物質の発生源及びその輸送過程の究 明が必要である。

また，筆者らは石狩大橋で先に掃流砂及び浮遊砂を観 測した ${ }^{3)}$ 。この観測では水面幅 $250 \mathrm{~m}$, 平均水深約 $9 \mathrm{~m}$ の 河道で, 垂直方向 $0.5 \mathrm{~m}$ 間隔，横断方向 17 測線上で浮遊 砂は 1 回あたり約 170 点, 掃流砂は 17 測線上の河床面で 測定している。測定項目はS.S, 掃流砂量のほかに各測 


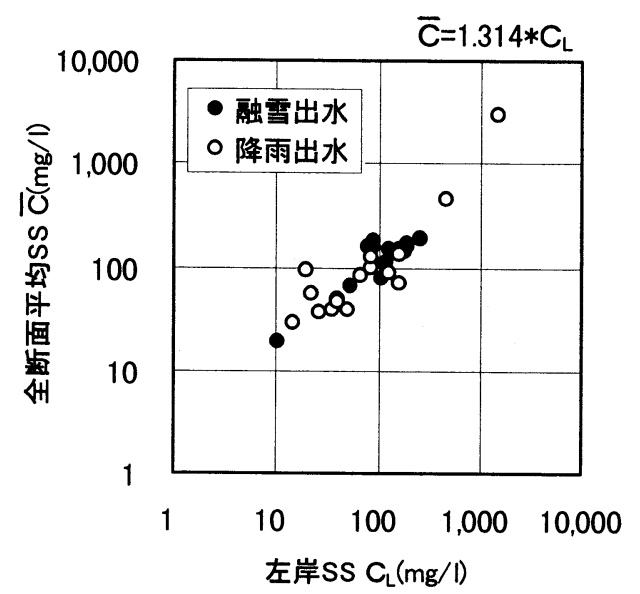

図-4 左岸 S.S と全断面平均S.S（石狩大橋）

点の水深, 流速である。また, 観測は融雪出水及び降雨 出水の増水期と減水期を比較できるように，観測時期を 設定し観測している。観測成果を流下断面全体の河川流 量 $Q$ と掃流砂量 $Q_{B}$, 総浮遊砂量 $Q_{s T}$ の関係で図 3 に示 している。図からわかるように，掃流砂量は河道内の水 理量に支配されて移動する現象であるから，融雪出水及 び降雨出水での違いは見られない。ところが, wash load を含む総浮遊砂量は，融雪出水と降雨出水で輸送量の相 違が顕著であり，同じ流量では降雨出水のほうが幾分多 く輸送されていることがわかる。また降雨出水では流量 $Q$ との相関性が良くないように見られるが，その原因は 増水期の輸送量は大きく, 減水期の輸送量が小さいこと によるものである。

このように, 融雪出水を伴う積雪寒冷地の河川におい て, 土砂輸送量を論じるにあたって基礎となる流砂量観 測は, 融雪出水及び降雨出水それぞれの出水で測定する ことが重要であり,また 1 つ出水にあっては, 増水期・ 減水期それぞれについて連続して観測する必要がある。

また，この流砂量観測值を用いて，河道断面内の S.S の分布形状を検討したが，その中から次に述べる水質自 動監視装置による毎時の濁度測定が河岸で行われている ことを考慮して, 河岸における S.S 観測の有為性を検討 した。

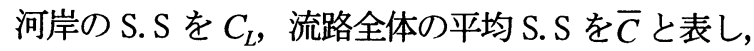
次式で求める。

$$
\begin{aligned}
& C_{L}=\frac{1}{q} \int_{a}^{h} c_{l} \cdot v_{l} \cdot d h \\
& q=\int_{a}^{h} v_{l} \cdot d h \\
& \bar{C}=\frac{1}{Q} \int_{0}^{B} \int_{a}^{h} c \cdot v \cdot d h \cdot d B \\
& Q=\int_{0}^{B} \int_{a}^{h} v \cdot d h \cdot d B
\end{aligned}
$$

ここに $q$ : 流路単位幅の流量 $\left(\mathrm{m}^{3} / \mathrm{s} / \mathrm{m}\right), c_{l}$ : 河岸測線の
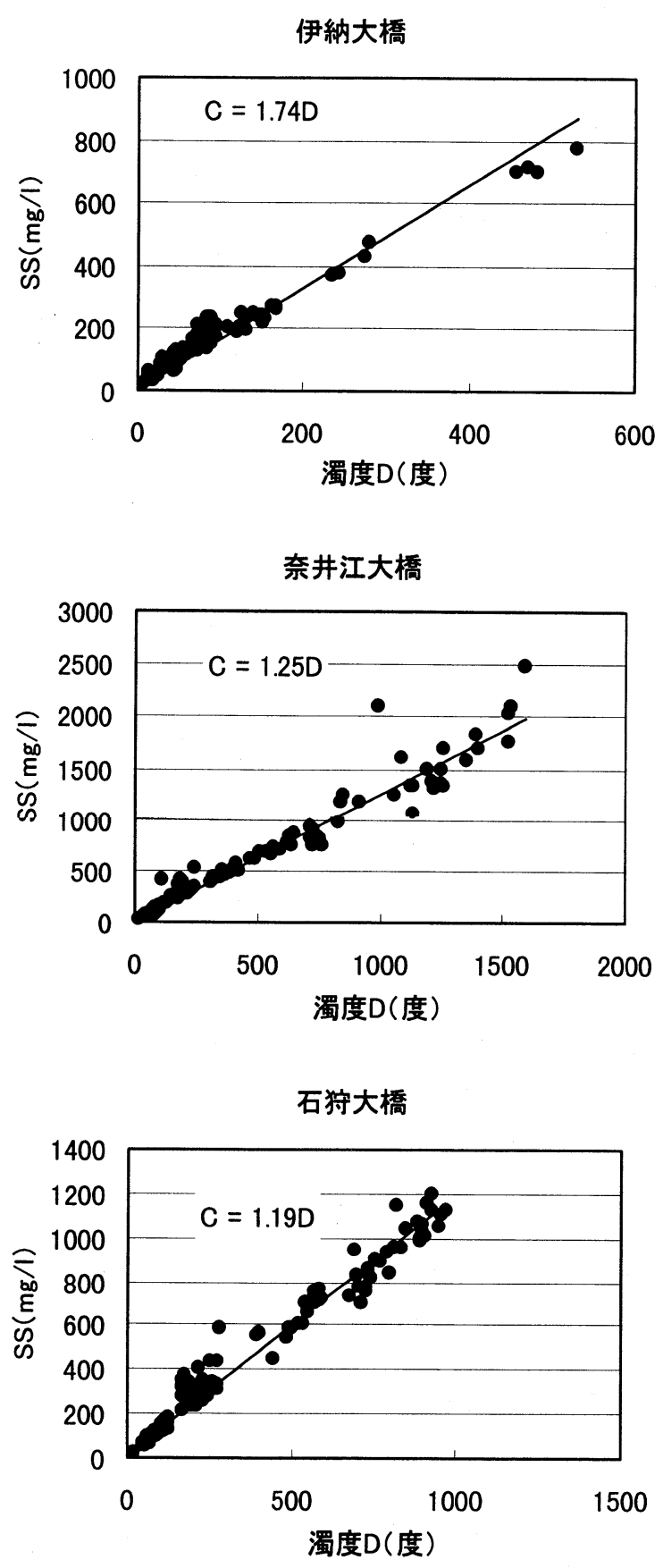

図-5 濁度と S. S

任意水深の $\mathrm{S} . \mathrm{S}\left(\mathrm{g} / \mathrm{m}^{3}\right), c$ : 任意地点の $\mathrm{S} . \mathrm{S}\left(\mathrm{g} / \mathrm{m}^{3}\right), v_{l}$ : 河岸測線任意水深の流速 $(\mathrm{m} / \mathrm{s}), v$ : 任意地点の流速 $(\mathrm{m} / \mathrm{s})$, $a:$ 境界層厚 $(\mathrm{m}), h:$ 水深 $(\mathrm{m}), d h:$ 区分水深 $(0.5 \mathrm{~m} \sim$ $1.0 \mathrm{~m}$ 間隔), $B$ : 河幅 $(\mathrm{m}), d B$ : 区分幅 (15m の測線間隔) 観測值によれば $C_{L}$ と $\bar{C}$ の関倸については, 図-4に示 すとおりで次の相関式を得た。

$$
\bar{C}=1.314 \cdot C_{L}
$$

この調査結果は, 危険性が少なく, また観測が容易で ある河岸においてS.S を測定することが，物質輸送量に 関するデータの蓄積を容易にすることを意味する。 


\section{（2）濁度と S. S}

北海道開発局は, 水質の監視を目的として, 図- 1 に示 す 3 箇所の河岸において, pH，D0, 電気伝導率, 濁度, $\mathrm{CN}, \mathrm{NH}_{4}$ の 6 項目を 1 時間毎に計測している。そのデータ のうち濁度の観測値に着目して，土砂輸送量に換算でき ないかを調査した。まず濁度データが計測されている 3 地点で採水した流水について，濁度（度）と S. S (mg/1) を同時に計測した。その計測方法は，（1）に述べた方法 と同じである。その結果，図-5に示すようにそれぞれの 関係は比例関係と見ることができる ${ }^{4)}$ 。

$$
C=\alpha \cdot D
$$

ここに $C: \mathrm{S} . \mathrm{S}(\mathrm{mg} / 1), D:$ 濁度(度), $\alpha$ : 換算係数

換算係数 $\alpha$ は, 測定地点によって異なった值を示して おり，測定する河川によって示される固有值と考えられ る。しかし，同一地点では，濁度值の大小，また融雪出 水と降雨出水の違いなどでは，あまり変化しない值と考 えて良い。

$\alpha$ が観測地点によって異なる要因は未だわからないが， 今回の 3 箇所の分析結果から見ると，上流側ほど大きい 值を示しており，このことは浮遊中の土砂粒径と関係す るとも考えられる。これらの関係を 1 つの例として，河 床砂砅の平均粒径 $\mathrm{d} \mathrm{m}$ との関係で表わすと図-6 の通り であるが，いずれにせよそれらの検証は今後の課題であ る。

しかし，今回の調査で濁度と S.S との関係が得られた ことは, 濁度 $D$ と流量 $Q$ の時間観測值が得られれば, または流量のハイドログラフは一般的にデータがそろっ ているので，何らかの方法で濁度の時間毎の值が予測で きれば，出水毎の S. S 輸送量の計算が可能となることを 示している。

\section{3. 濁度関数の分析}

出水時の濁度と流量は，流量が大きくなると濁度は大 きくなる関倸にある。しかし，出水の増水期と減水期で は同一流量に対する濁度は増水期が大きい。また，濁度 が最も大きい值が発生する時刻は，流量の最大值が発生 寸る時刻とは限らない。その例を図-7に示しているが， 石狩大橋 (流域面積 $12,697 \mathrm{~km}^{2}$ )においては，濁度が流量 に比べて先行しており，また毎時刻の濁度は，時系列的 に見て，流量の単位時間当たりの変化量 $d Q d t$ の時系列 変化と位相が合っている。また, 濁度と流量の関係は, 図-8 に示すとおり時刻毎に変動していて, 石狩大橋 $\left(12,697 \mathrm{~km}^{2}\right)$, 奈井江大橋 $\left(8,943 \mathrm{~km}^{2}\right)$, 伊納大橋 $\left(3,379 \mathrm{~km}^{2}\right)$ ともに増水期の濁度は大きく，減水期には小さくなり， 流量の変化に伴う濁度のヒステリシスは右回りのループ を描く関係が見られ，更には融雪出水に比較して降雨出 水のほうが濁度值が大きくなる傾向が見られる（図-9 参 照)。これは，土砂輸送量観測において指摘したとおり，

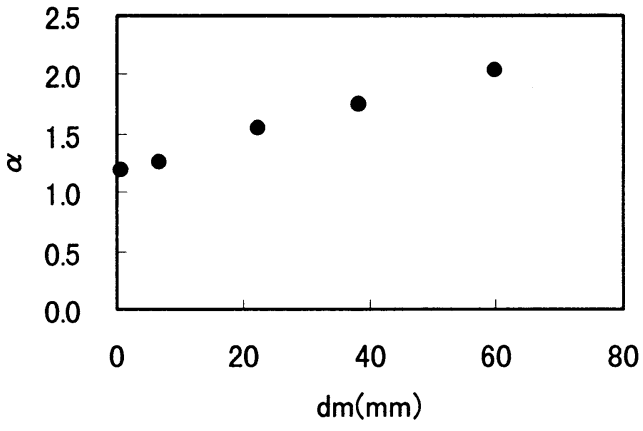

図-6 河床砂礫 $\mathrm{d} \mathrm{m}$ と $\alpha$
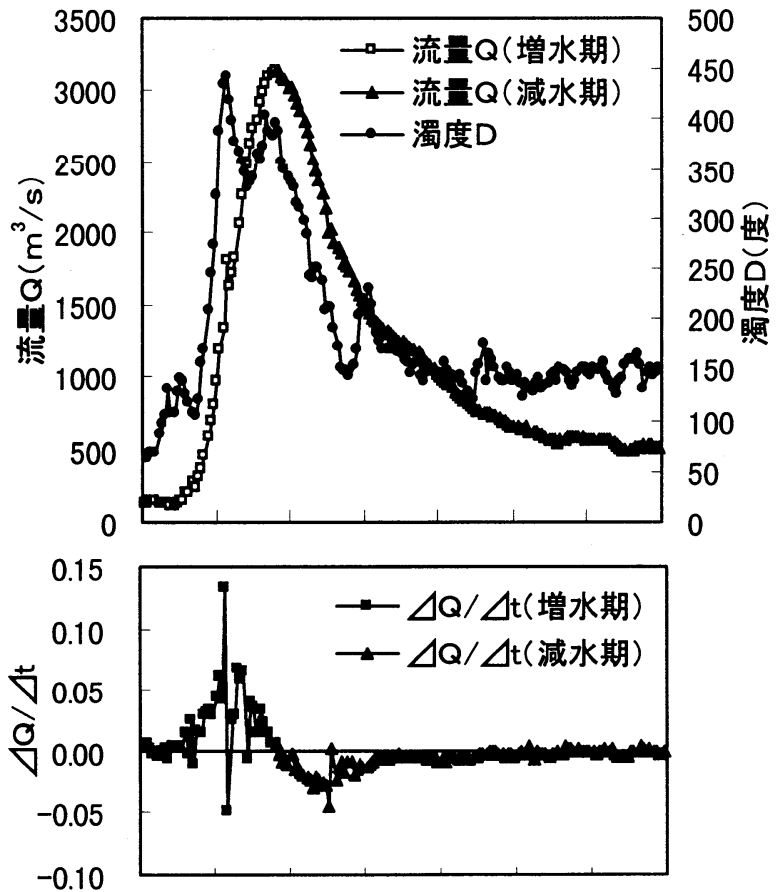

$\begin{array}{lllllll}10 / 19 & 10 / 20 & 10 / 21 & 10 / 22 & 10 / 23 & 10 / 24 & 10 / 25\end{array}$

月/日

昭和54年10月19日～25日 実測値(石狩大橋)

図-7 流量・濁度・ $\Delta \mathrm{Q} / \Delta \mathrm{t}$ の時間変化

総浮遊砂量は降雨出水の場合が大きいことと符合した結 果となっている。

これらの毎時の濁度 (度) と流量 $Q\left(\mathrm{~m}^{3} / \mathrm{s}\right)$ との関倸に着 目して，その関係を次式に示す簡単な濁度関数で考えて みる5)。

$$
D=K_{1} Q^{P_{1}}+K_{2} \frac{d Q}{d t}
$$

さらにS.S $C$ と濁度 $D$ には， $C=\alpha \cdot D$ の関係がある ことは先述のとおりであるので, 総浮遊砂量 $Q_{s}$ は式(7) を用いて次のように表わされる。

$$
Q_{s T}=\frac{\alpha}{\gamma} \times 10^{-6} \cdot\left\{K_{1} Q^{P_{1}}+K_{2} \frac{d Q}{d t}\right\} \cdot Q
$$

式(7)，（8)において $D:$ 濁度(度)，Q: 流量 $\left(\mathrm{m}^{3} / \mathrm{s}\right)$, $Q_{s T}:$ 総浮遊砂量 $\left(\mathrm{m}^{3} / \mathrm{s}\right), \gamma:$ 土砂の単位重量 $\left(\mathrm{t} / \mathrm{m}^{3}\right)$, $C: \mathrm{S} . \mathrm{S}\left(\mathrm{mg} / 1, \mathrm{~g} / \mathrm{m}^{3}\right), K_{l}, K_{2}, P_{1}, \alpha:$ 倸数 


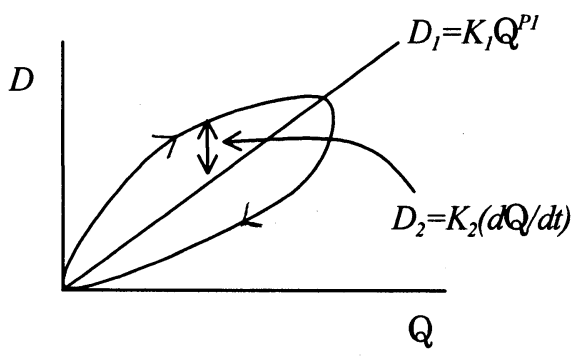

図-8＼cjkstart流量と濁度の関係

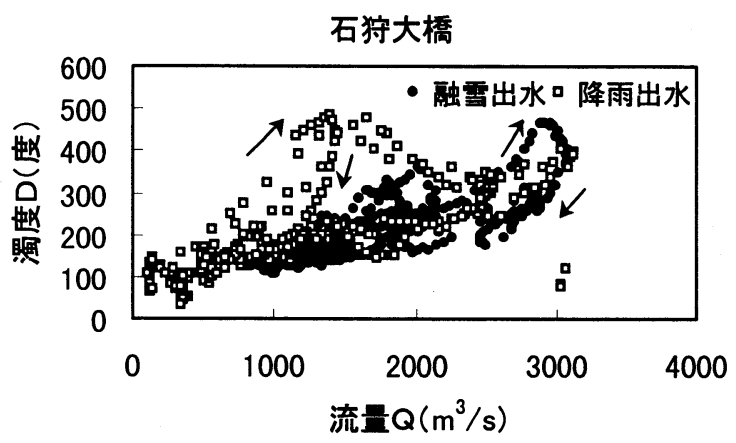

図-9 流量と濁度（出水各3例）

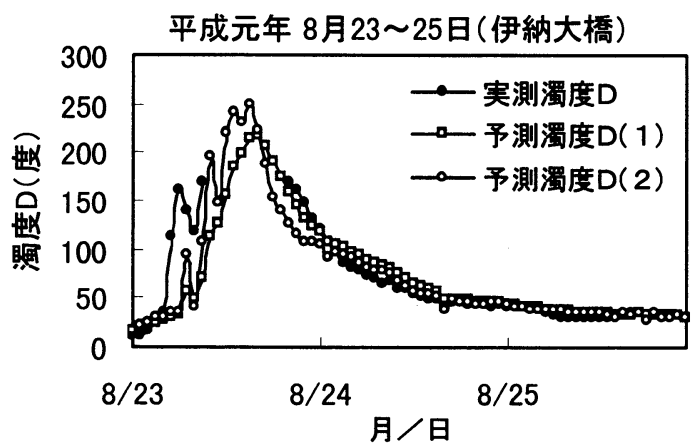

昭和54年10月19～25日（石狩大橋）

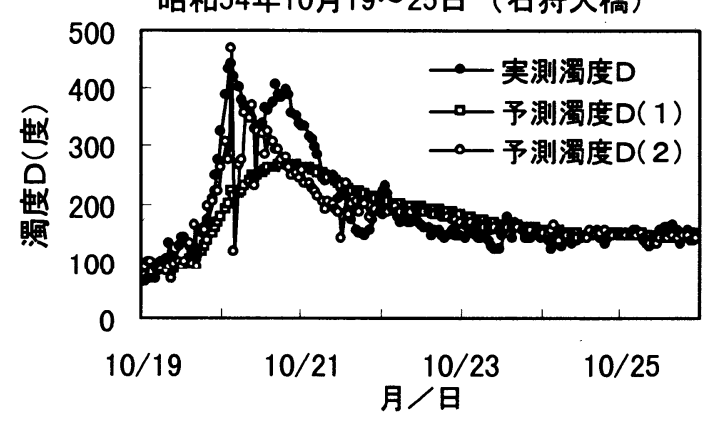

図-10＼cjkstart濁度関数による再現計算

濁度関数の適合性を検証するため，伊納大橋，奈井江 大橋, 石狩大橋の 3 観測所における融雪出水・降雨出水 それぞれ 3 洪水について, 毎時の流量から実測した濁度 を再現するために最も適合する平均した係数 $P_{l}, K_{1}, K_{2}$ を同定する。同定值を用いた濁度関数による再現計算結 果は図-10 に示す。予測濁度 $D(1)$ は式 (7) の第 1 項 のみで計算し, 予測濁度 $D(2)$ は第 2 項も使用した場合 である。予測濁度 $D(2)$ が良い再現が得られており，式

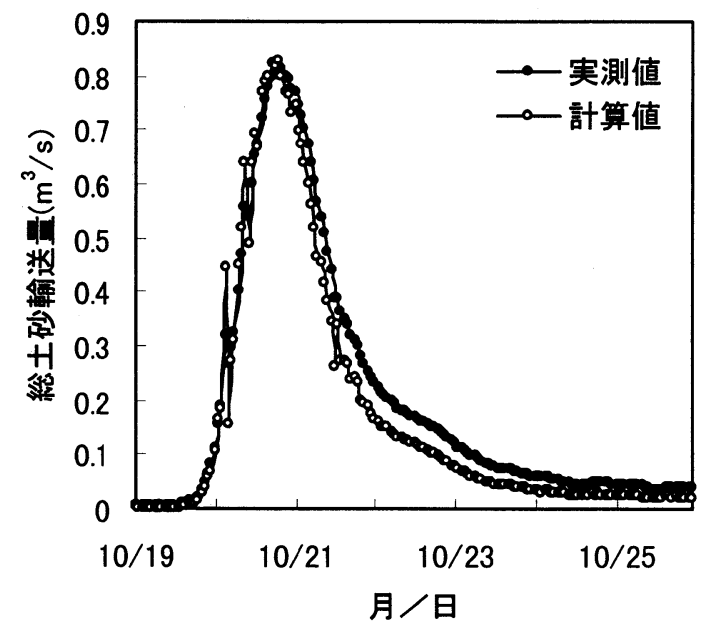

図-11 土砂輸送量計算例

（石狩大橋 S54. 10. 19～25）

（7）の妥当性がわかる。同定した值は $P_{1}$ は $0.6 〜 2.0$ の 範囲にあり，その值を観測所，出水毎に示寸までには至 つていない。また， $K_{1}$ は $10^{-1} \sim 10^{-3}, K_{2}$ は $10^{1} \sim 10^{3}$ と観 測所, 出水毎にランダムな值となり, これら倸数の変動 については今後検討を要する。

\section{4. 土砂輸送量の計算}

次に濁度関数と流砂量の相関式を用いて，降雨出水を 事例として, 石狩大橋における総土砂輸送量を計算し, 濁度関数の適合性を検証する。

まず濁度関数を用いる方法は次による。石狩大橋にお ける時間濁度を測定する水質自動監視装置は，石狩川の 左岸に設置されているので，濁度関数で計算した濁度は 河岸の值である。また, 河道全断面のS.S C は, 先に述 べた式 (6)，（5）を用いて，濁度值から求められる。さ らにS.S を含砂量と考え，これらの観測值による相関式 と濁度関数並びに流量 $Q\left(\mathrm{~m}^{3} / \mathrm{s}\right)$ を用いて, 総浮遊砂量 $Q_{s T}\left(\mathrm{~m}^{3} / \mathrm{s}\right)$ を求める (石狩大橋)。

$$
Q_{s T}=\frac{1.314 \cdot \alpha}{\gamma} \times 10^{-6}\left\{K_{1} Q^{P_{1}}+K_{2} \frac{d Q}{d t}\right\} \cdot Q
$$

石狩大橋においては， $\alpha=1.19 ， \gamma=2.65\left(\mathrm{t} / \mathrm{m}^{3}\right)$ を用 いて, $Q_{s}$ を計算する。また, $K_{l}, P_{l}, K_{2}$ は当該出水で水 質自動監視装置による実測值で同定した值を用い，計算 した。また，掃流砂量 $Q_{B}\left(\mathrm{~m}^{3} / \mathrm{s}\right)$ は，出水の増水期・减水 期ともに流量と一定の関係が見られるので, 石狩大橋に おける現地観測による相関式から求める (図-3 参照)。

$$
\text { 石狩大橋 } Q_{B}=2 \times 10^{-10} Q^{2}
$$

よって，総土砂輸送量 $Q_{T}$ が計算できる。

$$
Q_{T}=Q_{s T}+Q_{B}
$$

また，流砂量観測值を用いる方法は，図-3に示した総 浮遊砂量及ひ漳流砂量と河川流量との相関式を用いて, 総土砂輸送量を計算し, 前者の濁度関数を媒体とした土 
砂輸送量との比較を行った。総浮遊砂量 $Q_{s T}$ は式 (12), 掃流砂量 $Q_{B}$ は式 (10), 総土砂輸送量 $Q_{T}$ は式 (11) を 用いる。

$$
Q_{s T}=10^{-6} Q^{1.6908}
$$

石狩大橋における降雨出水の計算例を図-11 に示寸。 実測值 (○) は，図-3 に示寸流量と総浮遊砂・掃流砂の 関係を示す相関式を用いて算出したものである。計算値

（○）は，それぞれの出水について同定した倸数を用い て式 (9)，(10)，(11）により算出しており, 毎時間輸送 量の再現性は良いことがわかる。

\section{5. まとめ}

大きな流域を有する河川の土砂輸送量は, シルト, 粘 土などの微粒子で構成されている wash load が卓越して いるので，その土量を把握するため総浮遊砂量の観測を 行った。また，浮遊物質量を表わすS.S と濁度には，一 定の関係があることが確かめられた。次に，流量をパラ メーターとする濁度関数を用いて，その濁度を計算する 方法を提唱した。そして濁度関数から S.S と濁度の関係 を用いて総浮遊士砂量を推定する方法を考究し，その精 度を検討した。その結果，土砂輸送量の観測及びその分 析から次の諸点が明らかになった。

（1）出水時に河道を流下する輸送物質のうち土砂，総 窒素, 総リンは重量でおおむね $100: 1: 0.1$ の割 合である。

（2）同一流量で輸送される土砂量をみると，降雨出水 による輸送量は融雪出水による輸送量よりも大き く，出水原因別に輸送量を検討する必要がある。
（3）また 1 つの出水でも，増水期と減水期により土砂 輸送量に違いがあるので，それぞれの時間帯に観 測を行い，土砂輸送量の実態を把握する必要があ る。

（4）石狩川石狩大橋における土砂輸送量は総浮遊砂が 卓越し, 総浮遊砂量は掃流砂の $500 \sim 1,000$ 倍程度 大きい。

（5）濁度と S.S には一定の関係が有るものの，その関 係は観測地点により異なるので，観測地点毎に測 定する必要がある。

（6）出水時に見られる濁度の時間変化は，流量 $Q$ と流 量の時間変動量 $d Q d t$ との関係で示す濁度関数に よって表わすことができる。

（7）濁度関数, 濁度と S.S の関倸等から 1 出水当たり の総土砂輸送量の計算が可能である。

\section{参考文献}

1）河川審議会 : 流砂采の総合的な土砂管理に向けて，総合土 砂管理小委員会, 平成 10 年 7 月.

2）(財) 北海道河川防災研究センター: 観測値による物質輸送 量の推計, 平成 11 年 6 月.

3）北海道開発局 : 第 13 回北海道開発局技術研究発表会（河 川部門) 河床変動に関寸る調查研究最終報資料編, 昭和 45 年 2 月.

4）石狩川開発建設部: 流量 - 濁度観測資料, 平成 10 年 5 月.

5）渡辺浩司, 山口 甲: 濁度関数の支配因子に関する研究, 土木学会北海道支部論文報告集第 55 号 (B), pp.298 301, 1999.

(1999. 9.30 受付) 